\title{
BUDAYA MALU PADA MASYARAKAT TENGGER DAN PENGARUHNYA TERHADAP BUDAYA HUKUM PENGHINDARAN KONFLIK
}

\author{
Oleh : \\ Purnawan Dwikora Negara'
}

\begin{abstract}
This shame culture is developed and maintained to serve as a means of traditional social control/social control so that the Tengger people always behave in accordance with Tengger norms and customs so as to avoid conflict. Culture of shame in Tengger society greatly influences its legal culture, that influence can be seen / manifested in never conflicts. The efforts of the Tengger people to maintain their shame culture through a social control system in the form of: (a) religious education; (b) Education in the Family by developing the paugeran-paugeran Tengger; (c) Advice, namely advice given by the elderly to the young or fellow, and; (d) Social suggestion, namely instilling the values of fun through folklore and legends around Tengger.
\end{abstract}

Kata Kunci: Budaya Malu, Tengger, Budaya Hukum, Konflik

\section{PENDAHULUAN}

Menurut Anwar (2002), Selama ini hukum lebih dipahami oleh bangsa Indonesia sebagai produk ideologi belaka akibatnya hukum hanya menjadi alat status quo bagi penguasa. Mengembalikan hukum sebagai produk kebudayaan harus diupayakan dengan cara menegakkan budaya hukum (legal culture) dalam seluruh perilaku berbangsa dan bernegara. Budaya hukum yang harus ditumbuhkan adalah budaya hukum yang lahir dari kandungan ekspresi bangsa Indonesia sendiri, yang merupakan perwujudan dari nilai-nilai sebagai dasar pijakan dalam berbangsa dan bernegara.

Salah satu unsur budaya hukum yang terpenting adalah adanya "budaya malu" (shame culture) yang merupakan bagian paling penting dari adat ketimuran masyarakat Indonesia.

Menurut Soedjito (1986: 127) budaya malu adalah suatu nilai tradisional yang dikembangkan masyarakat untuk mengatur hubungan interaksi di antara anggota keluarga dan masyarakat secara keseluruhan. Nilai-nilai dalam hidup bermasyarakat diperlukan untuk menentukan tindakan atau sikap mana yang dianggap baik. Berdasarkan nilai-nilai inilah maka disusun norma-norma yang menentukan mana yang dianggap baik dan mana yang dianggap kurang baik.

Atas dasar norma atau kaedah-kaedah itu kemudian dijadikan pedoman bertingkah laku sehingga tidak terjadi bentrokan antara kepentingan-kepentingan manusia dalam pergaulan hidup.

Suatu budaya malu yang telah diresapi dengan mendarah daging oleh masyarakat dapat dikatakan adalah telah merupakan/menjadi lembaga kemasyarakatan, Dalam budaya malu bentuk lembaga kemasyarakatannya adalah perasaan hilangnya rasa kepercayaan masyarakat yang dipandang sebuah bentuk hukuman yang membuat seseorang berusaha untuk melakukan "pengendalian" diri lebih kuat, sanksi sosial macam ini justru lebih efektif dibandingkan dengan sanksi hukum normatif yang kadangkala tidak efektif untuk mencegah seseorang

${ }^{1}$ Fakultas Hukum, Universitas Widyagama Malang 
melakukan perbuatan melanggar hukum dan norma sosial lainnya.

Oleh karena itu, Menurut Soekanto (1983) suatu lembaga kemasyarakatan berfungsi untuk memenuhi kebutuhan-kebutuhan masyarakat. antara lain :

1. Memberikan pedoman pada anggota masyarakat bagaimana mereka harus bertingkah laku atau bersikap dalam menghadapi masalah-masalah dalam masyarakat.

2. Menjaga keutuhan dari masyarakat yang bersangkutan.

3. Memberi pegangan kepada masyarakat untuk mengadakan sistem pengendalian sosial yaitu sistem pengawasan dari pada masyarakat terhadap tingkah laku anggota-anggotanya.

Merefleksikan budaya malu dalam konteks kekinian di Indonesia, realitasnya menunjukkan bahwa bangsa yang kental dengan nilai-nilai ketimurannya ini dipandang telah mengalami degradasi dalam menjunjung tinggi budaya malunya.

Saat ini malu sudah mengalami pemutakhiran etika yang sangat hebat, malu bukan lagi perasaan yang harus diimplementasikan dalam konteks kehidupan bermasyarakat. Malu, bukan lagi menjadi sebuah etika atau rasa, sehingga semestinya semakin halus perasaan seseorang tentunya 'rasa malu'-nya akan semakin dapat membentuk kesadaran jiwanya terhadap dirinya sendiri dan masyarakat, namun yang terjadi justru sebaliknya, kesadaran jiwa itu semakin luntur bersamaan dengan hilangnya rasa malu. Malu, sudah dikalahkan oleh kepentingankepentingan yang berpangkal pada materi yang berwujud sederetan angka-angka kapitalistik (Arief, 2004)

Bukti yang nyata dan telah menjadi keseharian bangsa kita adalah korupsi. Sebagaimana telah diketahui bahwa pencurian uang negara atau rakyat (korupsi) di negeri kita tampaknya sudah dianggap sebagai hal yang biasa. Fenomena ini setidaknya bisa dicermati dari seringnya modus operandi yang selalu melibatkan lebih dari dua atau tiga pihak, bahkan secara kolektif. Demikian juga praktik-praktik penyelewengan dalam proses penegakan hukum seperti, mafia peradilan, proses peradilan yang diskriminatif, jual beli putusan hakim, atau kolusi Polisi, Hakim, Advokat, dan Jaksa dalam perekayasaan proses peradilan merupakan realitas sehari-hari yang dapat ditemukan dalam penegakan hukum di negeri kita.
Tentunya bila terjadi budaya hukum yang "kumuh" seperti itu, menurut Anwar (2002) hanya akan menjadikan hukum di negeri kita seperti yang pernah dideskripsikan oleh filsuf besar Yunani Plato (427-347 s.M) yang menyatakan bahwa hukum adalah jaring laba-laba yang hanya mampu menjerat yang lemah tetapi akan robek jika menjerat yang kaya dan kuat (laws are spider webs, they hold the weak and delicated who are caught in their meshes but are torn in pieces by the rich and powerful).

Implikasi yang dapat ditimbulkan dari budaya hukum demikian adalah tidak berjalannya penegakan hukum dengan baik dan efektif sehingga dapat menimbulkan kerusakan dan kehancuran diberbagai bidang (politik, ekonomi, sosial, dan budaya), selain itu buruknya penegakan hukum juga akan menyebabkan rasa hormat dan kepercayaan masyarakat terhadap hukum semakin menipis dari hari ke hari. Akibatnya, masyarakat akan mencari keadilan dengan cara mereka sendiri. Suburnya berbagai tindakan main hakim sendiri (eigenrichting) di masyarakat adalah salah satu wujud ketidakpercayaan masyarakat terhadap hukum yang ada (Arifin, 2007).

Oleh karena itu, perlu dilakukan revitalisasi budaya hukum pada masyarakat kita melalui nilai-nilai ketimuran bangsa kita yang telah ada/terbangun, yang salah satu diantaranya adalah budaya malu.

\section{PEMBAHASAN}

\section{Budaya Malu Pada Masyarakat Tengger}

Dalam rangka diskursus wacana revitalisasi budaya malu untuk mencegah konflik tentunya kita dapat memulai/menggali dari kenyataan di masyarakat apakah kita masih memiliki budaya malu.

Sebagaimana yang telah dijelaskan di atas bahwa budaya malu adalah suatu nilai tradisional yang dikembangkan masyarakat untuk mengatur hubungan interaksi di antara anggota keluarga dan masyarakat secara keseluruhan, di mana berdasarkan nilai-nilai itu kemudian disusun norma-norma yang menentukan mana yang dianggap baik dan mana yang dianggap kurang baik.

Pada masyarakat kita, salah satu masyarakat yang masih memegang teguh nilai-nilai tradisional mereka adalah 
masyarakat Tengger yang mendiami kawasan Gunung Bromo. Masyarakat Tengger dikenal sebagai masyarakat yang patuh memegang teguh adat istiadatnya, termasuk di dalamnya teguh memegang atau mentaati hukum adatnya, sehingga peristiwa sengketa hukum diantara mereka saja tidak pernah terjadi.

Menurut Negara et all (2006: 57-59), dalam penelitiannya tentang masyarakat Tengger menegaskan bahwa masyarakat Tengger adalah masyarakat yang patuh terhadap norma-norma adat, memiliki kesusilaan yang tinggi, keadaan masyarakatnya tenteram tidak pernah ada pencurian, setiap permasalahan dapat diselesaikan dengan mudah atas peranan orang tua yang berpengaruh melalui sistem musyawarah, segala pelanggaran cukup diselesaikan kepala desa dan biasanya mereka patuh atas putusan kepala desa.

Ditambahkan oleh Negara (2006: 59) bahwa masyarakat yang demikian tentu ada kaidah-kaidah yang tersembunyi di belakangnya, kaidah itu diantaranya budaya malu, dan budaya malu ini dalam hidup keseharian mereka selalu dijaga, dikembangkan, dan dipertahankan.

\section{Bentuk-Bentuk Budaya Malu pada Masyarakat Tengger}

Bagi masyarakat Tengger bahwa suatu perbuatan yang tercela sebagai akibat dari suatu kelakuan yang menyimpang akan menimbulkan malu, bukan saja malu pada diri mereka sendiri dan keluarganya, tetapi juga akan menjadi malu satu desa. Oleh karena, itu masyarakat di Tengger berusaha untuk tidak menjadi "rasanan", "omongan" atau gunjingan, atau bahan tertawaan satu desa, karena satu ulah kecil saja di Tengger dapat secara cepat menyebar ke seluruh desa.

Demikian juga bagi orang Tengger kebanggan dan malu orang Tengger itu meskipun itu merupakan kebanggan atau malu perorangan akan ditanggung bersama oleh seluruh desa, sebaliknya kebanggan ataupun malunya desa akan dirasakan juga oleh masyarakat desa, misalnya saja mayarakat bisa merasa malu bila desa tidak mampu menyelenggarakan upacara adat karena ketiadaan biaya, malu ini akan menjadi beban bagi warga seluruh desa karena apabila terdengar atau diketahui masyarakat Tengger dari desa lain warga satu desa akan kehilangan muka karena dianggap tidak menghormati adat istiadat warisan leluhur.

Atas dasar hal ini kemudian orang Tengger sangat peka terhadap penilaian dan pandangan lingkungan masyarakatnya terhadap dirinya karena keterikatannya pada kelompok sangat kuat.

Menurut Durkheim (1985: 112-115) bahwa keterikatan kepada kelompok adalah salah satu faktor moral yang mengatur tingkah laku. Dalam konteks ini masyarakat Tengger untuk menjaga keterikatan kelompoknya itu agar tetap kuat dalam arti tingkah lakunya dipertahankan sesuai dengan norma-norma dan adat istiadat yang berlaku yang dijunjung tinggi, salah satunya mereka lakukan dengan dengan cara mengembangkan rasa malu.

Dalam amatan peneliti sumber utama mengembangkan rasa malu ini adalah direfleksikan dari persoalan-persoalan yang mungin muncul yang berkaitan dengan tanah dan upacara-upacara adat, yang selanjutnya direfleksikan juga dari persoalan-persoalan yang menyangkut harta benda selain tanah dan kesusilaan.

Bagi masyarakat Tengger apabila timbul persoalan dalam hidupnya yang berkaitan dengan tanah dan upacara-upacara adat hal ini menurut Dukun Soetomo Desa Ngadas, maupun Pak Mulyadi Bromo Putro selaku tokoh masyarakat Tengger (Wawancara, 8 Agustus 2016) akan menimpakan rasa malu pada diri masyarakat Tengger tersebut, baik secara pribadi maupun kelompok dengan bentuk rasa malu yang mereka sebut dengan wirang.

Wirang merupakan perasaan malu yang kuat yang dialami oleh seseorang setelah ia melakukan sesuatu perbuatan yang sangat tercela oleh masyarakat karena melanggar norma masyarakat yang sangat penting. Menginterpretasikan wawancara dengan Dukun Soetomo Desa Ngadas (Wawancara 8 Agustus 2016), yang dimaksudkan norma yang sangat penting ini adalah perbuatan yang 
dapat mempertemukan pelanggaran atas norma kesusilaan, norma kesopanan (etik), dan norma agama, dan bahkan norma hukum.

Dalam kasus pengingkaran atas normanorma yang menyangkut adat istiadat tentang hal tanah maupun upacara-upacara religi, rasa malu yang dalam itu muncul karena utamanya malu kepada Sang Hyang Widi Wasa, roh leluhur, dan roh penjaga desa yang juga disertai rasa malu kepada orang lain pada komunitas masyarakat Tengger baik satu desa maupun di luar desa.

Rasa malu yang begitu mendalam ini disebabkan karena adanya pandangan dari masyarakat Tengger terhadap tanah, yang memandang bahwa tanah itu memiliki dua makna sentral/penting dalam kehidupan mereka di mana tanah dipandang sebagai pusat religi dan tanah dipandang sebagai sumber penghidupan anugerah dari Sang Hyang Widhi (Tuhan YME), sebagai sumber penghidupan tanah merupakan sarana yang digunakan untuk mengabdi kepada-Nya melalui hasil bumi yang telah dihasilkannya.

Oleh karena itu, upacara adat atau pujan masyarakat Tengger kental berhubungan dengan tanah, karena bagi mereka tanah dianggap sebagai benda yang suci/sakral, yag wujud kesakralannya misalnya dapat dilihat dari pandangan mereka yang membagi tanah suci/sakral itu kedalam beberapa golongan yakni padanyangan, kuburan, petilasan, sanggar, kutugan, dan tegal (bumi).

Menelantarkan tanah atau mengalihkan tanah ke pihak luar desa merupakan sesuatu hal yang tabu dan pantang karena dianggap melanggar adat istiadat atau norma yang telah ditetapkan, yang dalam hal ini kalau dicermati lebih dalam adalah dipandang tidak menghormati Sang Hyang Widi, roh leluhur, maupun roh penjaga desa, yang ternyata apabila dikaji lebih dalam lagi hal itu sama halnya dengan menghancurkan atau menghilangkan agama atau adat istiadat Tengger itu sendiri karena tidak ada lagi sarana upacara/pujan Tengger yang bisa dijalankan karena tanahnya telah hilang, yang hal itu berarti juga mematikan eksitensi dukun sebagai salah satu komponen yang menjaga dan meneruskan tradisi Tengger.

Oleh karena itu, pengembangan rasa malu yang disebut wirang dalam hal dimungkinkannya pelanggaran norma-norma yang berkaitan dengan tanah dan upacaraupacara adat tak lain sebetulnya makna dibalik itu untuk lebih menjaga ketenggeran orang Tengger sendiri.

Bentuk perilaku lain selain yang berpusat pada tanah dan upacara-upacara religi yang pada gilirannya/perkembangannya dapat disebut wirang adalah perilaku-perilaku kriminal yang berkaitan dengan tanah/tegalan dan kesusilaan, misalnya saja seseorang secara sengaja mengambil rumput, kayu, hasil panen lantas ketahuan, apabila setelah perbuatan itu diketahui dan dapat dikelola dengan baik penyelesainnya maka belum menjadi wirang karena ada kesadaran diantara para pihak yang bisa memahami kekhilafan pihak lain karena anggapannya mungkin terpaksa melakukan itu karena tidak ada waktu, misalnya saja karena hari sudah sore sementara ternak yang dipelihara segera membutuhkan pakan, maka untuk mencari pakan di hutan sudah tidak mungkin lagi maka jalan pintasnya adalah mengambil rumput yang ditanam di tegal tetangganya (Wawancara dengan Dukun Ngadas Soetomo, 8 Agustus 2016).

Dalam hal kesusilaan yang biasanya menyangkut hubungan seorang laki-laki dengan perempuan di luar batas-batas norma yang ada dipandang sebagai wirang, karena perbuatan yang dilakukan akan menimbulkan aib bagi desa (misalnya menghamili seorang perempuan di luar nikah).

Bentuk pengembangan rasa malu lainnya yang terdapat di Tengger adalah isin, isin adalah malu yang tidak punya masalah, kalau wirang malu yang mempunyai masalah. Isin ini merupakan perasaan malu pada orang yang misalnya berkekurangan dalam satu hal (utamanya dalam bidang harta, mungkin juga kepandaian, ataupun penampilan). Orang merasa isin kalau ia berada bersama orang yang menurut pandangannya lebi dari dirinya. 
Berikutnya teridentifikasi rasa malu yang disebut dengan kelimputan, rasa malu ini dipandang sebagai setengah wirang dan setengah isin, yang sebetulnya hal ini merupakan wirang dengan derajat malunya lebih rendah, hal ini karena sebenarnya kesalahan yang dia lakukan adalah bukan sebuah kesengajaan. Misalnya saja dia berbicara sesuatu yang menurut sangkanya benar yang kemudian hal ini menjadikan pihak yang diajak bicara menjadi memiliki persepsi lain yang kurang pas kemudian menjadikan dirinya (pihak yang mengajak bicara) menjadi kehilangan muka karena pembicaraannya yang kurang pas.

Rasa malu selanjutnya yang dikembangkan adalah kepengkok, di mana kepengkok ini adalah rasa malu yang dapat berpotensi menjadi isin, kepengkok bisa terjadi misalnya saja dia salah bicara dengan orang tua, atau dia misalnya tidak memiliki uang sepeserpun lantas ke luar rumah dan di jalan bertemu orang, dia menjadi malu takut ketahuan kalau tidak memiliki uang, padahal orang tersebut belum tentu menyangkakan demikian atau mengetahui kalau dirinya tidak punya uang.

Rasa malu-rasa malu yang terjadi dan ada pada masyarakat Tengger ini sebenarnya merupakan bentuk kompromi atas pengekangan diri dari anggota kelompok/masyarakat Tengger tentang apa yang ingin mereka inginkan sendiri sekalipun keinginan itu menurut mereka melanggar adat istiadat yang ada, kompromi ini sebagai bentuk kontra prestasi agar ia diterima, disukai, atau dianggap wong oleh masyarakatnya, karena mereka takut akan pengucilan dari kelompok yang akan dirasakannya sebagai sanksi yang sangat menekan (Mboeik, 1982: 107).

Upaya masyarakat Tengger untuk melakukan kompromi dalam kelompoknya demi terwujudnya sebuah komunitas yang harmoni dan serasi dengan tetap mematuhi norma-norma yang telah dijunjung tinggi komunitasnya, yakni dengan penciptaan mekanisme rasa malu itu telah menjadi sebuah kebudayaan dalam menjamin berjalannya ketraturan dalam masyarakatnya, yang hal ini menurut Geertz (1973: 52) bahwa kebudayaan sebenarnya adalah serangkaian mekanisme kontrol yang tertuang dalam kaidah-kaidah dalam masyarakat yang mengatur pola kelakuan, dan budaya malu adalah pengatur pola kelakuan itu.

\section{Fungsi Budaya Malu pada Masyarakat Tengger}

Kebudayaan adalah suatu sistem yang terpadu yang mengandung nilai-nilai yang diterima dan berlaku di dalam masyarakatnya. Kebudayaan mengandung aturan-aturan sebagai untuk mengendalikan pola kelakuan sosial atau social control. Pengendalian sosial dilakukan dengan ajaran, ajakan ataupun paksaan agar individu mematuhi atau menyesuaikan diri dengan peraturanperaturan, kebiasaan-kebiasasan yang dipergunakan oleh masyarakatnya (Roucek, 1987:83).

Dengan demikian, tentunya fungsi dari mengembangkan budaya malu pada masyarakat Tengger pada dasarnya adalah sejalan dengan pernyataan di atas yakni, sebagai sarana pengendalian sosial atau kontrol sosial tradisional. Makna tradisionalnya adalah bahwa pengendalian sosial itu dilakukan berdasarkan cara-cara dan adat istiadat yang dikembangkan dalam lingkungan masyarakat Tengger itu sendiri dengan menyesuaikan kondisi masyarakat Tengger. Orang Tengger beranggapan bahwa perbuatan yang menyimpang dari adat istiadat adalah ora ilok dan apabila dilanggar selain mendapatkan sanksi sosial dari masyarakat yang bahkan ditambahi dengan denda materi, juga dipandang mendapatkan sanksi dari Sang Hyang Widhi Wasa, para roh leluhur, dan para roh penjaga desa, hal ini karena keyakinan mereka apa yang mereka perbuat akan mendapat karam atau balak (kuwalat) bagi dirinya dan bagi seluruh masyarakat desa.

Pengendalalian sosial tradisional itu juga misalnya dapat dilihat dari nilai-nilai yang terkandung dalam prinsip-prinsip atau ajaran-ajaran hidup pada masyarakat Tengger yang kesemuanya mengarah pada menjaga budaya malu (Sutarto, 1997: 67-68). Kita bisa 
cermati misalnya saja pada ajaran bahwa untuk mencapai kesejahteraan hidup, orang Tengger diwajibkan untuk menjauhi malima dan memperjuangkan tercapainya walima. Yang dimaksud dengan malima adalah maling (mencuri), main (judi), madat (minum candu), minum (mabuk karena minuman keras) dan madon (main perempuan); sedangkan walima yang mereka perjuangkan adalah waras (sehat jasmani dan rokhani), wareg (cukup makan), wastra (cukup sandang), wasis (cukup ilmu pengetahuan) dan wisma (memiliki tempat tinggal yang layak).

Juga pada ajaran yang mengarah kepada keharmonisan dan kelestarian dalam persaudaraan, seperti yang terdapat dalam sesanti pancasetia (lima petunjuk kesetiaan), yakni setya budaya (taat dan hormat kepada adat), setya wacana (kata harus sesuai dengan perbuatan), setya semaya (selalu menepati janji), setya laksana (bertanggung jawab terhadap tugas) dan setya mitra (selalu membangun kesetiakawanan).

Dalam kehidupan sehari-hari orang Tengger juga berpegang kepada pralima yang mereka sebut sebagai kawruh buda, yakni prasaja (sederhana), prayoga (menunaikan kebajikan), pranata (taat kepada penguasa), prasetya (setia kepada janji dan bertanggung jawab) dan prayitna (selalu waspada).

Selain ajaran-ajaran tersebut di atas, masih ada ajaran lain yang hanya dikenal oleh para sepuh (orang yang telah berusia tua) yang disebut ajaran welas asih pepitu (tujuh ajaran kasih sayang), yakni: (1) cinta kasih kepada Hong Pukulun atau Kang Maha Agung, (2) ibu pertiwi (bumi tanah), (3) bapabiyung (ayah dan ibu atau kedua orangtua), (4) jiwa-raga (jasmani dan rokhani), (5) sepadhapadhane ngahurip (sesama makhluk hidup), (6) sato kewan (binatang piaraan), dan (7) tandur tuwuh (tanaman). Welas asih pepitu ini dilengkapi dengan apa yang disebut dengan dasar pitung perkawis (tujuh macam prinsip) yang tercermin dalam beberapa doa dukun Tengger. Dasar pitung perkawis tersebut adalah sebagai berikut.

1. Hong mandera pulun sak empuna dumerek ing sasi Kasada meningaken ing tamah (Semoga Yang Maha Agung memberi cahaya terang (keselamatan) setelah kurban Kasada dilaksanakan).

2. Milanga sarining patra kang gumelar ngajenganing sarining patra sak srep ngambek sak tengahe manah (Lihatlah roh sejati yang menyejukkan hati).

3. Kang adoh pinarekaken kang parek pinariki nang angon aron-aron (Yang berada di tempat yang jauh mendekatlah, yang berada di sekitar merapatlah, yang sedang mengembara berhentilah)

4. Angrasuka ajang kang pinayu dening Sang Hyang Sukma (Masuklah ke dalam tempat yang telah dalam perlindungan Sang Hyang Sukma).

5. Jiwa raga sinusup bahan warna sanga (Jiwa dan raga yang memiliki sembilan lubang hawa nafsu).

6. Ngelongono jiea remana maha ngimbuhana banyu kahyuwanan (Hindarilah angkara murka agar mendapat kebahagiaan).

7. Denira negja nyandra nitis sepisan kerta rahayu pelinggihane Hyang Hyang Lurah Dukun Kaki Dukun sagune anak putu sami andaya Pulun (Datanglah wahai roh sejati ke tempat yang telah disediakan oleh Lurah kaki dukun untuk-Mu (Hyang) agar kami beserta anak cucu bahagia dan sejahtera).

Tampaklah jelas bahwa budaya malu mereka merupakan sarana pengendalian atau kontrol sosial bagi masyarakat Tengger agar berperilaku sesuai tuntunan norma-norma dan adat istiadat di Tengger yang dapat menghindarkan konflik.

Menurut Horton dan Hun (1991: 203) Suatu tata kelakuan sosial, baik yang bersifat menyimpang ataupun yang patuh, dikendalikan terutama oleh norma dan nilai yang dihayati. Terjadinya penyimpanganpenyimpangan disebabkan oleh adanya gangguan pada proses penghayatan dan pengalaman nilai-nilai tersebut dalam tata kelakuan seseorang. Pengendalian sosial ada yang berbentuk formal berupa hukum atau 
sanksi yang sudah dilembagakan dan pengendalian informal berupa sanksi dari lingkungan. Cara mengendalikan diri atau pengendalian dalam bermasyarakat antara lain adalah: (a) Pengendalian sosial-eksternal yaitu dari masyarakat, hal ini dapat berupa pengakuan dan penerimaan untuk tindakan dan kelakuan yang diharapkan masyarakat dan sebaliknya. Karena kalau melanggar norma-norma, pola-pola, adat kebiasaan yang berlaku akan mendapatkan sanksi yang mengakibatkan malu. Secara formal pelanggaran ini dapat berupa pelanggaran hukum negara yang akan mendapatkan hukuman legal dari negara untuk individu yang melakukannya, dan ini akan berakibat pula pada keluarga dan lingkungannya. Secara informal mereka akan mendapat malu karena ulah yang menyimpang dari salah satu anggotanya, atau hanya dengan sanksi dari masyarakat berupa luka sosial, karena melanggar ketentua norma, adat kebiasaan yang berlaku meskipun bukan merupakan pelanggaran hukum negara sebagai pengendalian sosial-eksternal. Pengendalian sosial-eksternal adalah imbalan sosial terhadap konformitas dan sanksi hukuman yang diberikan kepada seseorang yang melakukan tindakan penyimpangan.

Pengendalian sosial-internal karena penghayatan norma-norma dan nilai-nilai tersebut, sehingga muncul pengendalian diri dan kesadaran, meskipun tak ada orang lain yang memperhatikan, namun dirinya sendiri akan mencegah untuk melakukan hal-hal yang menyimpang atau munculnya keinginan untuk menyimpang sangat kecil kemungkinannya.

Jadi, peranan "malu" dalam Tengger adalah sebagai suatu alat pengendali dalam berkelakuan dan bertindak, dengan kata lain kesadaran rasa malu sebagai mekanisme kontrol dalam perilaku masyrakat Tengger. Mekanisme kontrol yang dimaksud disini adalah proses pengendalian kelakuan dan tindakan orang Tengger dalam masyarakat sesuai dengan pola-pola, norma-norma, adat kebiasaan yang seharusnya sehingga menciptakan keteraturan.
Nilai moral malu telah membatasi kelakuan yang tidak sesuai, atau yang tidak dapat diterima oleh masyarakat lingkungan tempat dia berada. Internisasi ini akan membuat "malu" menjadi suatu kontrol dalam berkelakuan meskipun tidak ada orang yang memperhatikannya. Kalau perasaan malu atau penyesalan sudah jauh meresap dalam proses internalisasi pembentukan individu, maka secara otomatis segala tingkah lakunya akan terkendali tanpa adanya pengaruh di luar, perhatian atau hukuman dari lingkungannya, karena menurut Suparlan (1984: 85) dan Geertz (1973: 44-52) bahwa kebudayaan mengatur hidup kita setiap saat, mulai dari lahir sampai mati, disadari atau tidak ada tekanan terus-menerus pada diri kita untuk mengikuti tipe-tipe kelakuan tertentu yang telah diciptakan orang lain untuk kita, hal ini karena kebudayaan adalah serangkaian mekanisme kontrol yang tertuang dalam kaidah-kaidah dalam masyarakat yang mengatur pola kelakuan.

\section{Budaya Malu dan Pengaruhnya pada Budaya Hukum Masyarakat Tengger}

Bagi masyarakat yang sedang membangun, hukum selalu dikaitkan pada usaha-usaha untuk mencapai taraf kehidupan yang lebih baik dari pada yang telah dicapai sebelumnya, sedang untuk mencapai taraf kehidupan yang lebih baik itu diperlukan kondisi masyarakat yang kondusif, dalam arti berperilaku sesuai dengan ketentuan hukum sehingga tidak menimbulkan konflik atau pun kekacauan dalam pencapaian tujuan itu. Dengan demikian, di sini ternyata hukum memiliki peranan yang sangat penting dalam arti fungsi hukum ternyata tidak sekedar menjadi sebagai alat kontrol sosial belaka melainkan lebih dari itu, yakni mampu menggerakkan masyarakat agar bertingkah laku sesuai dengan ketentuan hukum guna mencapai suatu keadaan masyarakat yang dicita-citakan tadi.

Sementara itu untuk bertindak atau bertingkah laku sesuai dengan ketentuan hukum diperlukan adanya kesadaran hukum masyarakat, hal ini karena kesadaran hukum masyarakat merupakan semacam jembatan 
yang menghubungkan antara peraturan hukum dengan tingkah laku hukum anggotaanggota masyarakat. Sedang yang termasuk dalam kesadaran hukum adalah kategori nilainilai, pandangan-pandangan, serta sikap-sikap yang mempengaruhi bekerjanya hukum, yang oleh Lawrence M. Friedman (1975) disebut dengan budaya hukum (legal culture).

Kondisi carut marutnya suatu masyarakat yang bertingkah laku tidak sesuai dengan ketentuan hukum sementara itu masyarakat tersebut menyandarkan diri kepada hukum dalam rangka pembangunan untuk meningkatkan taraf hidupnya adalah potret dari rendahnya kesadaran hukum masyarakat itu sendiri, padahal menurut Rahardjo (2006), hukum itu adalah refleksi perilaku kita sendiri.

Rendahnya kesadaran hukum masyarakat dapat ditelisik dari masih ada tidaknya 'budaya malu' pada masyarakat itu sendiri, Menurut Bertens dalam Khalid (2006) shame culture atau budaya malu adalah tingkah laku yang diregulasikan dengan lebih menekankan pada rasa malu. Budaya malu merupakan salah satu unsur budaya hukum yang terpenting dari adat ketimuran kita, hal ini karena budaya malu telah menjadi bagian dari kehidupan masyarakat kita.

Bila kita menilik pada Masyarakat Tengger, bahwa rasa malu yang ada dan dikembangkan oleh masyarakat Tengger yang tadinya hanya merupakan adat kebiasaan, kemudian menjadi adat istiadat, norma, tata kelakuan dan lain-lain yang menyangkut kehidupan dalam bermasyarakat, yang ditularkan pada generasi berikutnya di mana generasi berikutnya menyerap kebiasaankebiasaan itu, baik diserap mulai dari lingkungan keluarga yakni tempat dia dibesarkan dan dididik dalam bertingkah laku yang benar yang sesuai dengan lingkungan masyarakatnya telah memampukan mereka merasakan perasaan-perasaan tertentu seperti rasa malu, rasa bersalah, rendah hati, dan lainlain. Dari rasa-rasa yang dirasakan itu telah menjadi suatu alat pengendali dalam berkelakuan dan bertindak.
Budaya malu yang dalam hal ini mampu menjadi alat pengendalian dalam berkelakuan dan dalam bertindak itu, dalam gambaran Sunarto (1991), Sutarto (1997), dan Negara (2006) yang telah melakukan penelitian di Tengger dalam kurun waktu yang berbeda mengatakan bahwa masyarakat ini merupakan masyarakat yang selalu menjaga harmonisasi kehidupannya dan sebuah daerah yang dikenal hampir tidak pernah ada tindak kejahatan, padahal ternak dan hasil panen mereka yang memiliki nilai ekonomi cukup tinggi cukup mereka letakkan di ladangladang yang relatif cukup jauh dari rumah mereka.

Tentunya suasana harmonis, tenteram, dan tanpa konflik ini tidak terjadi begitu saja, namun melalui sebuah proses yang panjang lewat upaya menjaga dan mengembangkan budaya malu tersebut, yang dalam hal ini menurut Durkheim bahwa manusia itu ditata dan dibentuk oleh adat kebiasaan dan hukum yang berlaku dalam masyarakat di mana dia berada dan dibesarkan. Dengan berinteraksi dengan sesamanya dan lingkungannya terbentuk suatu kebiasaan yang menjadi adat dan norma yang berlaku di lingkungan kelompok itu tentang apa yang biasa dilakukan dan tidak biasa dilakukan. Di dalam kelompok atau masyarakat itu tumbuh dan berkembang suatu adat istiadat, norma, dan tata cara yang biasa dilakukan. Hal-hal yang baik untuk semua yang harus dilakukan sedangkan hal-hal yang buruk harus dihindari karena akan merugikan, Kebiasaan ini meliputi hal-hal yang seharusnya diikuti sebagai perilaku sopan dan hal-hal yang menyangkut keharusan untuk kesejahteraan semua (1990: 18).

\section{Upaya-upaya Mempertahankan Budaya Malu pada Masyarakat Tengger sebagai Upaya mencegah Konflik}

Pembinaan budaya hukum itu dapat dilakukan dengan mengedepankan lagi, menggali, atau merevitalisasi lagi budaya malu. Untuk itu dibutuhkan adanya pendidikan hukum secara berkesinambungan dari sejak dini dalam masyarakat. Pendidikan itu dapat berupa suri tauladan dari orang tua 
dalam keluarga, dan juga secara informal dalam berbagai kesempatan baik di lembaga pendidikan dasar, menengah, atas, maupun perguruan tinggi hukum/non-hukum serta organisasi kemasyarakatan lainnya (Anwar, 2002).

Pada masyarakat Tengger upaya-upaya yang merupakan sistem pengendalian budaya malu agar tetap bertahan di jiwai dilakukan melalui metode: pendidikan agama, pendidikan dalam keluarga, petuah-petuah, dan sugesti sosial.

\section{a. Pendidikan Agama}

Bagi masyarakat Tengger pendidikan agama merupakan sarana untuk mempertebal keyakinan dan mendalami ilmu agama serta untuk membina akhlak (etika). Pendidikan agama ini biasanya dilakukan di tempattempat ibadah sebagaimana agama yang ada di Tengger, misalnya saja bagi yang muslim mengaji di Musholla, bagi yang beragama Hindu ke Pura atau Sanggar Pamujan.

Seiring dengan aktivitas keagaman itu para tokoh agama dan juga Pak Dukun mempergunakan kesempatan untuk membentuk sikap, tingkah laku, dan tatakrama kelakuan muridnya sesuai dengan sistem kepercayaan, norma, dan aturan-aturan agama. Sikap, tingkah laku dan tata kelakuan yang diharapkan, agar muridnya dapat bersopan-santun dengan sesamanya, dengan kerabat (keluarga), dengan orang yang lebih tua dari padanya dan dengan gurunya.

\section{b. Pendidikan dalam Keluarga}

Fungsi pendidikan dalam keluarga pada masyarakat Tengger lebih dominan untuk membina sikap, tingkah laku, dan tata kelakuan serta tata cara mencari nafkah hidup, hal ini karena fungsi lain sudah diambil alih oleh lembaga-lembaga pendidikan formal. Dalam kehidupan suatu keluarga pada masyarakat Tengger peranan seorang ayah dan ibu sangat penting dalam mengendalikan budaya malu, agar para anggota keluarganya antara lain tidak melakukan pekerjaanpekerjaan yang dapat membuat malu.

Peran penting orang tua itu adalah utamanya dalam mengkomunikasikan paugeran-paugeran pada lingkungan keluarganya Maksudnya adalah demi menghormati roh-roh leluhur serta ketaatan kepada kepada pimpinan mereka meneruskan pepatah-petitih yang disampaikan pimpinan kepada keluarga mereka masing. Pepatahpetitih itu bisa bersumber dari ajaran agama/religi yang disampaikan dukun atau tokoh agama maupun ajaran sosial kemasyarakatan yang disampaikan kepala desa.

Komunikasi ini berada di ruang sentral keluarga yakni, pawon (tungku perapian), karena salah satu ciri masyarakat Tengger adalah di rumahnya memiliki pawon. Pawon ini tidak sekedar sebagi ruang keluarga dia juga berperan sebagai ruang pendidikan, termasuk di dalamnya pendidikan atas normanorma yang berlaku di lingkungan masyarakat Tengger.

Salah satu yang menonjol dari 'pendidikan di ruang tungku' adalah budaya malu, budaya malu ini dalam keseharian selalu dijaga, dikembangkan, dan dipertahankan oleh masyarakat Tengger. Misalnya saja bagi orang Tengger akan sangat malu jika tidak bisa berpartisipasi dalam kerja bakti, membantu tetangga yang punya hajat, dan sebagainya.

Mengkomunikasikan paugeran pada dasarnya adalah menjaga nilai-nilai primer/nilai-nilai dasar, sebab nilai-nilai baru dalam hukum adat dan kebiasaan kerap selalu dilandasi oleh nilai-nilai lama, yakni nilainilai primer atau dasar itu. Nilai-nilai primer merupakan nilai-nilai dasar yang tidak begitu saja berubah. Sebagai gambaran Meskipun Jepang telah mencapai tingkat industrialisasi yang tinggi, tetapi ada nilai-nilai dasar atau nilai-nilai primer tertentu yang tidak berubah. Jika ada kereta api bertubrukan, menteri yang bersangkutan akan meminta mengundurkan diri, meskipun bukan kesalahannya langsung, di sini rasa malu merupakan nilai primer yang tidak berubah bahkan kalau perlu rasa malu itu ditebus dengan nyawanya sendiri (Sudjito, 1998: 127).

\section{c. Petuah-petuah}

Petuah adalah nasehat atau pelajaran yang baik yang diberikan oleh seseorang 
kepada orang lain agar orang yang menerima petuah itu dapat bertingkah laku dan berbuat sesuai dengan nilai-nilai yang diinginkan oleh pemberi petuah itu. Hubungan antara pemberi dan penerima petuah biasanya terjadi dalam bentuk hubungan vertikal dan hubungan horizontal. Dalam hubungan vertikal petuah itu berasal dari orang-orang yang lebih tua atau orang yang mempunyai otoritas keilmuan atau otoritas kekuasaan. Sedangkan dalam hubungan horizontal petuah itu berasal dari orang-orang setara antara pemberi dan penerima petuah.

Pemberian petuah ini cukup efektif karena adanya ajaran bagi masyarakat Tengger yang tertuang dalam sesanti pancasetia (lima petunjuk kesetiaan), yakni setya budaya (taat dan hormat kepada adat), setya wacana (kata harus sesuai dengan perbuatan), setya semaya (selalu menepati janji), setya laksana (bertanggung jawab terhadap tugas) dan setya mitra (selalu membangun kesetiakawanan), yang menjadikan orang Tengger dapat menerima masukan dari segala pihak (Wawancara dengan Mulyadi Bromo Putro, 9 Agustus 2016).

Sedang isi-isi petuah telah terformulasi dalam hal atau prinsip untuk menjauhi malima dan memperjuangkan walima. Yang dimaksud dengan malima adalah maling (mencuri), main (judi), madat (minum candu), minum (mabuk karena minuman keras) dan madon (main perempuan); sedangkan walima yang mereka perjuangkan adalah waras (sehat jasmani dan rokhani), wareg (cukup makan), wastra (cukup sandang), wasis (cukup ilmu pengetahuan) dan wisma (memiliki tempat tinggal yang layak).

\section{d. Sugesti Sosial}

Bagi masyarakat Tengger sugesti sosial juga memegang peranan pentingan dalam mempertahankan budaya malu karena dapat menanamkan kepada anak akan nilai-nilai yang diinginkan oleh agama dan adat istiadat. Anak akan memperoleh nilai-nilai tersebut melalui cerita rakyat atau legenda yang diturkan turun temurun yang isinya banyak digali dari adat istiadat suku Tengger.
Misalnya saja Legenda Roro Anteng Joko Seger, Legenda Gunung Bathok, Legenda Kyai Dadap Putih atau Legenda SetiyaSetuhu.

Misi cerita dan legenda ini dapat mempengaruhi anak-anak, para pemuda, maupun orang tua supaya dapat berpikir dan bertingkah laku sesuai dengan nilai-nilai yang sesuai dengan kehidupan bermasyarakat di Tengger.

\section{PENUTUP}

Sistem pengendalian diri pada mereka benar-benar dijalankan, kejahatan macam pencurian harta benda di kampung-kampung rumah penduduk, pemerkosaan, dan bahkan pembunuhan tidak pernah terjadi. Perbuatan tindak pidanan yang ada hanyalah kriminalitas biasa yang berkaitan dengan persoalan perladangan (rumput, kayu, sayur) dan persoalan kesusilaan yang menyangkut hubungan pemuda dan pemudi belaka.

Secara konseptual, budaya hukum yang terkolaborasi dengan budaya malu pada hakikatnya merupakan sosok ideal dari sebuah kesadaran hukum masyarakat. Oleh karena itu maka pembinaan budaya hukum mempunyai peranan yang sangat penting bagi pembentukan (atau pembimbingan) kesadaran hukum yang dipandang dapat berpotensi surut, melemah, atau rusak.

\section{$-000-$}

\section{DAFTAR PUSTAKA}

Alfian, 1985. Persepsi Masyarakat Tentang Kebudayaan. Jakarta: Gramedia.

Alkostar, Artidjo (ed). 1997. Identitas Hukum Nasional. Jogjakarta: FH-UII

Alisjahbana, Sutan Takdir. 1974. Values as Integrating Forces in Personality, Society and Culture. Kuala Lumpur: University of Malaya Press

Bungin, Bungin. 2007. Analisis Data Penelitian kualitatif: Pemahaman Filosofis dan Metodologis ke Arah 
Penguasaan Model Aplikasi. Jakarta: Raja Grafindo persada

Bush, Arnold H.. 1978. Psychology, Behaviour in Perspective., New York: John Wiley \& Sons

Durkheim, Emile. 1990. Pendidikan Moral, terj. Lukas Ginting, Jakarta: Erlangga.

Faisal, Sanapiah. 1990. Penelitian Kualitatif: Dasar-dasar dan Aplikasi. Malang: Yayasan Asih Asah Asuh.

Friedman, M. Lawrence. 1975. The Legal System: A Sosial Science Perspective. New York: Russel Sage Foundation

Geertz, Clifford. 1973. The Interpretation of Cultures. New York: Basic books

Horton, Paul B \& Hunt. 1984. Sosiologi I dan II, terj. Aminuddin Rain dan Tita Sobari. Jakarta: Gelora Aksara Pratama

Ihromi, Tampi Omas. 1993. Antropologi dan Hukum. Jakarta: Yayasan Obor Indonesia

Koentjaraningrat, 1994. Kebudayaan Mentalitas dan Pembangunan. Jakarta: Gramedia.

Masriani, Yulies, Tiena. 2004. Pengantar Hukum Indonesia. Jakarta: Sinar Grafika.

Mboeik, Pieter B. 1982. "Perasaan Bersalah dan Perasaan Malu pada Masyarakat Priyayi Jawa di Solo". Thesis. Bandung: IKIP

Moleong, Lexy J. 2001. Metode Penelitian Kualitatif.

Bandung: Remaja Rosdakarya

Rahardjo, Satjipto. 2006. Sisi-sisi Lain dari Hukum di Indonesia. Jakarta: Penerbit Kompas

Progresif. Jakarta: Penerbit Kompas

Sostrodihardjo, Soedjito. 1998. "Kedudukan Hukum Adat dalam Industrialisasi" dalam Hukum Adat dan Modernisasi
Hukum, ed. M. Syamsudin dkk. Jogjakarta-FH-UII

----------. 1986. Transformasi Sosial: Menuju Masyarakat Industri. Jogjakarta: PT. Tiara Wacana.

Soemitro, Ronny Hanitijo. 1990. Metodologi Penelitian Hukum dan Jurimetri. Bandung: Ghalia Indonesi

Soekanto, Soerjono. 1983. Sosiologi: Suatu Pengantar. Jakarta : Rajawali

Swartz, P. 1963. Psychology, The Study of Behavior. New york: D. van Nostrand

Warassih, Esmi. 2005. Pranata Hukum Sebuah Telaah Sosiologis. Semarang: Suryandaru Utama

\section{Penelitian:}

Ubbe, Ahmad, et.al,. 1999. "Pengembangan Budaya Hukum dalam Pembangunan Nasional”. Laporan Penelitian. Jakarta: BPHN

Negara, Purnawan D. 2006. "Perilaku Hukum masyarakat Tengger terhadap Tanah: Studi di Desa Ngadisari, Kec. Sukapura, Kab. Probolinggo”. Laporan Penelitian. Malang: LP2M-UWG

Sutarto. 1997. "Legenda Kasada dan Karo Orang Tengger Lumajang". Disertasi. Jakarta: Program Pascasarjana UI

Sunarto, et al. 1991. "Sikap masyarakat tengger terhadap Norma-norma yang Berlaku di Desa Ngadisari, Kecamatan Sukapura, Kabupaten Probolinggo”. Laporan Penelitian. Jember: Pusat penelitian Universitas Jember

\section{Makalah:}

Faisal, Sanapiah. "Pendekatan Penelitian Kualitatif: Hakekat, Karakteristik, dan Variasi" makalah Lokakarya Penelitian, di Univ. Widyagama Malang, 3 Oktober 2006

\section{Koran dan Internet:}

Arifin, Firdaus. 2007. "Problema Penegakan hukum di Indonesia" dalam 
www.sarwono.net, diakses tanggal 28 Juli 2016

Anwar, Yesmil. 2002. "Budaya Malu dan Budaya Hukum”. dalam Kompas, 1 Juli 2002

Anonim. 2008. "Melawan Hukum dalam Tipikor: Judicial Review" tentang Unsur Melawan Hukum (wederrechtelijkheid) dalam UU Pemberantasan Tindak Pidana Korupsi”" dalam http://www.pnsleman.com diakses 1 Agustus 2016

Khalid. Muhamad. 2006. "Koruptainment dan Budaya Malu” dalam www.nlew.org, diakses tanggal 28 Juli 2016

Pitaloka, Ardiningtiyas Pitaloka. 2007. "Rasa Bersalah dan Rasa Malu" dalam http://www.e-psikologi.com diakses 2 Agustus 2016

Sihotang, Kasdin. 2008. "Eksistensialis Rasa Malu” dalam http://www.koranindonesia.com/2008/0 7/05/eksistensialis-rasa-malu diakses 1 Agustus 2016

Soemardi Soelaiman dan Selo Soemardjan. 2007. "Budaya" dalam www.wikipedia.org, diakses tanggal 2 Agustus 2016 